\title{
Take Down syndrome out of the abortion debate
}

$\mathrm{T}$

rig Palin, the 5-month-old son of vice presidential candidate Sarah Palin, has drawn enormous public notice to Down syndrome. For that, many in the US and Canadian Down syndrome communities are grateful.

But as the mother of 2 children with Down syndrome, it makes me very nervous. I'm not willing to see my kids used as poster children for the anti-abortion movement. Rather, I see the attention that Sarah and Trig Palin are bringing Down syndrome as an opportunity to take the issue of prenatal screening out of the abortion debate once and for all.

Singling out a condition by offering routine screening and enabling selective abortion sends a strong value judgment

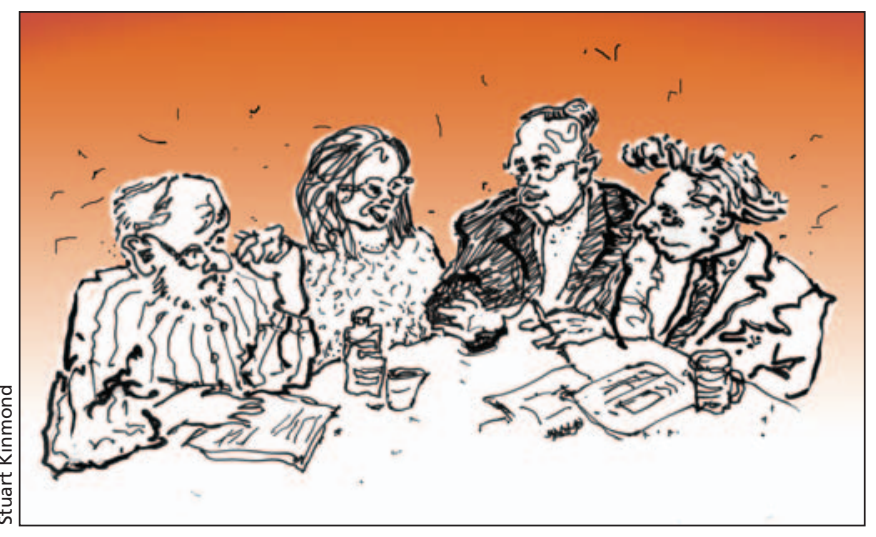

having a baby with Down syndrome didn't scare me. Most pregnant women, however, have neither a role model, nor unbiased, balanced and complete information about Down syndrome. Many have never met a person with Down syndrome or talked to the family of a person about potential quality of life. Trying to predict the future based solely on their genes opens the door to discrimination, anxiety, fears and underestimating social and environmental factors in maintaining health. Progress that was made over many generations, in terms of inclusion and equal rights, could be lost in less than one.

When I was pregnant with my first child I found a leaflet in the obstetrician's office entitled "Maternal Serum Testing." The information about Down syndrome mentioned that "....some lead productive lives but many have very limited physical and mental abilities."

My "risk" of having a baby with Down syndrome, according to the leaflet, was 1 in 294. My husband and I had made up our minds long before I became pregnant that we would keep and love our baby, no matter what. We declined both the blood screen and the amniocentesis. Some interpreted this as a decision based upon religious beliefs, but, in fact, it was a personal choice.

I was in the fortunate position of knowing some wonderful people living with Down syndrome, so the prospect of with Down syndrome, and are unprepared for the information revealed by screening or testing. That means they're not making a fully informed choice.

We want complete information to be available prior to the offer of screening. Some hospitals don't make any information publicly available, while others offer only a summary of medical problems that may, or may not, occur. Even medical websites feature very little "other" information about Down syndrome kids: their smiles, their giggles, the unconditional love they give their parents; the fact that today, most of these kids lead pretty normal, happy and healthy lives.

Palin said she was "devastated and shocked" to receive a prenatal diagnosis of Down syndrome. With abortion rates hovering around the $90 \%$ after Down syndrome is diagnosed, she isn't the only one who has feared the unknown.

If we don't start giving pregnant women real information about Down syndrome before they are screened, I fear what will happen when a new generation of early, accurate and safe pre- natal tests is commercially launched next year. In the near future, we can expect prenatal tests for many other conditions and diseases, such as a predisposition to autism or cancers. Who decides which conditions women should be screened for? Will people with identifiable conditions experience intolerance, financial hardship?

The best way to create a society that embraces (genetic and other) differences is to educate and engage the public and to support individual choices, whatever they are.

In the Netherlands the Department of Health has consulted the public since 2002 on prenatal genetic testing, by means of citizen panels. In addition, its Centre for Congenital and Hereditary Disease (Erfo-centrum) provides reliable, complete (not limited to medical) and up-todate information about genetic and/or hereditary conditions. With unbiased information at their fingertips, about 50\% of Dutch women currently decline prenatal screening for Down syndrome.

At the end of the day, when I look at my daughters, April and Hazel, both living with Down syndrome, I don't see the genetically flawed children that prenatal screening is trying to eliminate. I see kind-hearted, happy children who are giants in loving and living, who enrich our human genetic diversity and who teach me and everyone they meet what it is to truly feel.

\section{Renate Lindeman}

Spokesperson

Down Syndrome Belongs

Dartmouth, NS

Have you got an opinion about this article? Post your views at www.cmaj.ca. Potential Salon contributors are welcome to send a query to salon@cma.ca. 